\title{
Fish Species Diversity of Nagaram Tank of Warangal, Andhra Pradesh
}

\author{
Narasimha Ramulu, $K^{1}$ and Benarjee, $G^{2}$ \\ Fisheries Research Laboratory, Department of Zoology Kakatiya University, Warangal
}

\begin{abstract}
The fish production plays a significant role in the human economy. India has vast potential for development of inland fisheries. In the present study an attempt has been made to evaluate the physico-chemical characteristic features and fish fauna diversity of Nagaram tank, located at sub urban of Warangal. It proposed to enhancement of fish production in a sub urban perennial water body in Warangal district of Andhra Pradesh. The study was conducted during June 2007 to May 2010. The study revealed that different regions of the tank receive variable precipitation and hence meteorological factors governing the physico-chemical properties of the tank which in turn influence planktonic diversity and so that all the physico-chemical and biological factors have direct influence on the fish production.

From the present study, it observed that all the physico-chemical parameters are at nearly permissible limit at all the 4 identified stations. It is estimated that the fish fauna of Nagaram tank consists of 30 species belonging to 13 families. Among the collections 13 species of Cypriniformes, order Siluriformes consists of 7 species, Channiformes consists of 03 species, Perciformes 05 species, Osteoglossiformes 01 and order Atheriniformes consists of one species. Therefore, it is suggested that the immediate measures may be taken to avoid further contamination of this tank which has been started contaminated due to anthropological activities. Finally it may be concluded that the Nagaram tank is rich in fish diversity and is still in a position to set a good example of conservation of native fish fauna by the sustainable management practices.
\end{abstract}

Keywords: - Physico-Chemical Characters, Fish Diversity and Production, Significance and Conservation.

\section{Introduction}

Aquaculture has occupied a special status not only because of its contribution to food resources but also in view of its contribution to quality diet. Fish is one of the most important sources of animal diet. Fish is a valuable source of protein and occupied a significant position in the socio-economical fabric of South Asian countries. India has rich biological heritage that qualifies it as one of the twelve-mega diversity nations of the world (Gadgil, 1996). There are 24,600 species of known fishes, which comprises almost half the number of total vertebrates. In which only 400 species are commercially important. Among the available fish species of the world at least $20 \%$ of freshwater fish species are already extinct and in serious decline owing to the ecological degradation and mismanagement of natural resources and overexploitation.

Warangal district has several tanks, temporary and permanent spread out over through the district. The vast stretches of these freshwater bodies have good scope for fisheries. The district has rich fish fauna and there is a need to contemplate measures to protect the genetic resources. The main threat for the decline of various fish fauna may be due to indiscrimination, fishing of juveniles, industrialization, urbanization and destruction of natural environment, further deteriorating the situation. There is a need to take measures to protect the genetic resources of fish fauna, which are depleting enormously. The recent study henceforth has been contemplated to verify the fish germplasm resources in the freshwater bodies in the district. This study has given a vivid picture on the status of both torrential and plain water farms of Icthyofauna and its biodiversity.

Studies have been made on Ichthyofaunal diversity of various freshwater bodies in India during the last few decades (Jayaram 1981, Jhingran 1983, Dutta et al., 2001, Mishra et al., 2003). However, scanty information is available from this region of India (Murthy 2002). Chandrashekhar et al., (2004) enumerated limnological studies with respect to pisciculture in Saroornagar Lake. Pawar et al., (2006) studied fish fauna of Pethwadaj dam, Nanded. Kulkarni et al., (2008) studied fish and fisheries of Derala Tank, Dist. Nanded, Maharashtra. Rohankar (2009) studied biodiversity of fishes in Aheri lake of Maharashtra. Ravindar (2010) studied biodiversity of fishes in Dharmasagar reservoir, Warangal District, Andhra Pradesh.

In the present study it is aimed to evaluate the freshwater fish fauna in the Warangal district. The lack of information on the Ichthyo-fauna is a big handicap for popularizing little known fish variety in a particular ecosystem. Thus there is need to survey fish fauna associated with different fresh water habitats, which will help in planning methods for their production and effective exploitation (Sharma and Nayak, 2001). This study is also aimed to suggest remedial measures for the development of fisheries sector and also to recommend 
some conservative measures so that the fish germplasm resources of this region may be protected and preserved for their richness.

\section{Materials And Methods}

Most of the water bodies in Warangal and around the city such as ponds, lakes, tanks and streams have become polluted as a consequence of increasing industrialization, urbanization and other developmental activities for the last ten years. Nagaram tank of Hasanparthy mandal, near to $12 \mathrm{~km}$ from Kakatiya University Campus. Nagaram tank located a latitude $79^{0}-34^{\prime}-00^{\prime}$ ' West $79^{0}-36^{\prime}-00^{\prime \prime}$ East and longitude $18^{0}-4{ }^{\prime}-15^{\prime}$ ' South $18^{0}-5$ ' $-45^{\prime \prime}$ North. The water capacity of the tank 97.42 metric cubic meters.

Fishes were collected personally by using nets and the help was also taken from the local fishermen. The fish were collected from the landing sites along the tank soon after they were caught. They were brought to the laboratory for the identification and they were then preserved in $10 \%$ formalin for further observation. The fishes were identified up to species level following the standard procedures lain in the literature, (Day $1875 \&$ 1878; Mishra 1962; Srivastava 1985; Jayaram 1981; Menon 1999 \& 1988; Dutta and Srivastava 1988; Talwar and Jhingran 1991 and Murthy (2002)). The checklist of identified fish fauna was prepared and presented in the (Table - 1and 2).

\section{Results And Discussions}

Inland fisheries in India have great potential of contributing to the food security of the country. Reservoirs and lakes are the main resources exploited for inland fisheries and understanding of fish faunal diversity is a major aspect for its development and the sustainability management. The change in the composition of fish assemblage indicates variation in the water (Jhingran 1983, Vijay Kumar and Paul 1990). Fishes constitute nearly half of the number of vertebrate fauna found in the world. Total 39,900 vertebrate species are recognized all over the world; over 21,723 are living species of fishes of which 8,411 are of fresh water and 11,650 marine species. In India total fishes recorded are 2500, out of which 930 are fresh water and 1570 are marine fishes (Jayaram, 1999). Fresh water total lakes and ponds will probably contribute a major role to fulfill the additional requirement of fish and to improve the socio-economic status of the rural areas of a particular region (Jayabhaye et al., 2006).

In the present investigation, 30 species were recorded belonging to 6 Orders among which order Cypriniformes were dominant by contributing 13 species. The fish fauna of 30 species belonging to 13 families. Among which 13 species are Cypriniformes viz. Catla cattla, Cirrhinus mrigala, Labeo rohita, Labeo potail, Labeo pongusia, Labeo calbasu, Cyprinus carpio carpio, Punctius sarana sarana, Punctius chola, Punctius ticto ticto, Amblypharyngodon microlepis, Salmostoma bacaila and Lepidocephalus guntea, belonging to family Cyprinidae, only one species of Cypriniformes belonging to family Cobitidae namely Lepidocephalus guntea. Order Siluriformes consists of 7 species belonging to four families, Clarias batrachus, Heteropneustes fossilis, Mystus bleeker, Mystus vittatus, Mystus cavasius, Wallogo attu, Ompok bimaculatus. Three species belongs to Bagridae, two species belongs to Siluridae, each one species belongs to family Clariidae and Heteropneustidae respectively. Order Channiformes consists of three species Channa punctatus, Channa striatus and Channa orientalis belongs to family Channidae. Order Perciformes consists of five species Anabus testudineus, belongs to family Anabantidae, Mastacembelus armatus and Mastacembelus puncalus belongs to family Mastacemblidae, Glosogobius giuris giuris belongs to family Gobiidae, Nandus nandus belongs to family Nandidae. Order Osteoglossiformes consists of one species Notopterus notopterus belongs to family Notopteridae and order Atheriniformes consists of one species Xenontodon cancilla belongs to family Belonidae (Table-1 and Fig-1).

The studies on Ichthyofaunal diversity from different fresh water bodies of India have been carried out during the last few decades (Raju Talwar and Jhingran 1991; Menon, 1999; Sarkar and Benerjee, 2000; Mishra et al., 2003; Das and Chand, 2003; Sharma et al., 2004 and Pathak and Mudgal 2005). Goswami and Goswami (2006) have identified 54 fish species belonging to 36 genera under 22 families in Jamalai wet land in Assam. Yadav (2006) enlisted 77 species from Tadoba National Park, of which 46 species are common while 31 are uncommon. Lakes in India support rich variety of fish species, which interns, support the commercial exploitation of the fisheries potential (Krishna and Piska, 2006). Battul et al., (2007) studied the fish diversity from Ekrukh lake near Solapur, Maharashtra and reported the fish diversity is correlated with biological and various physico-chemical parameters that regulate the production and distinction of different species of the fishes. Sharma et al., (2007) reported 29 species of fishes belonging to six orders from Krishnapura lake, Indore and stated that Cypriniformes was dominant with 15 species followed by Siluriformes with 6 species. Due to more fecundity of major carps and suitable environmental condition relatively higher population density of Cypriniformes was evident in the tank. Kulkarni et al., (2008) studied fish and fisheries and recorded the annual total production of fish was about 150 tonnes/year in Derala tank, Dist. Nanded, Maharashtra. Dhankand et al., (2008) also reported 29 fish species from Sagar reservoir, Jhabua district of Madhya Pradesh which includes 21 
species from order Cypriniformes, 2 species from order Perciformes, and 2 species from order Mastacembliformes. Vyas et al., (2009) observed fish diversity and habitats of fishes in Narmada river. Anish Dua and Prakash (2009) studied distribution and abundance of fish populations in Harike Wetland A. Ramsagar site in India. Similar observations were found in present study. Earlier studies on water quality of some fresh water bodies in relation to fish culture were also made by Pawar and Shendge (2009); Negi (2009); Nooralam et al., (2009) and Ramu et al., (2009). Pawar and Pandarkar (2011) studied on water quality in relation to pisciculture of Kelewadi lake, Maharashtra.

With recent scientific advances and new strategies we can conserve aquatic resources and ensure its genetic diversity. We being the fishery scientist, have to promote fishery and endeavour to enhance the fish production to improve the socio-economic conditions of traditional fish farmers. According to vision 2020 document even after 50 years of independence still there is a lot to be done in fishery sector and what has been done so far in this sector is only a drop in the ocean. Therefore there is a need to take measures, which have to be initiated to protect and preserve the fish genetic resource and few of them or also at the verge of extinction in this region. The fish germplasm resource of this region exhibits a combination of both torrential and plain water forms. They occupy diverse ecological regime in their distribution. In this context the present study has been undertaken which is a bid to demonstrate the need of this agro-industry to improve the living standards of fishery folk, to enhance food security and also to promote the fishery sector in Warangal district of Andhra Pradesh.

The present study elucidates the ecological significance of water bodies to increase fish growth and production. Because the physico-chemical parameters, Primary productivity of the lakes directly influence the fish growth and production, the diversity and distribution of zooplankton also might have influence on fish fauna found in these waters. Therefore keeping this vital ecological factor in view, major water body has been choose and an attempt has been made to study the physico-chemical, biological status and also the fish fauna diversity of the tank which is one of the major fish producing tank in this area. The data thus obtained has been taken as basic criteria to suggest the remedy to enhance the fish growth and fish production not only in this water body but also in other water bodies too in this region.

Table - 1: ORDER WISE ICTHYOFAUNA DIVERSITY OF WARANGAL DISTRICT

\begin{tabular}{|c|c|c|}
\hline Sl.No. & Order & Number of species available \\
\hline 1 & .Cypriniformes & 13 \\
\hline 2 & Siluriformes & 07 \\
\hline 3 & Perciformes & 05 \\
\hline 4 & Channiforms & 03 \\
\hline 5 & Osteoglossiformes & 01 \\
\hline 6 & Antheriformes & 01 \\
\hline & Total & $\mathbf{3 0}$ \\
\hline
\end{tabular}

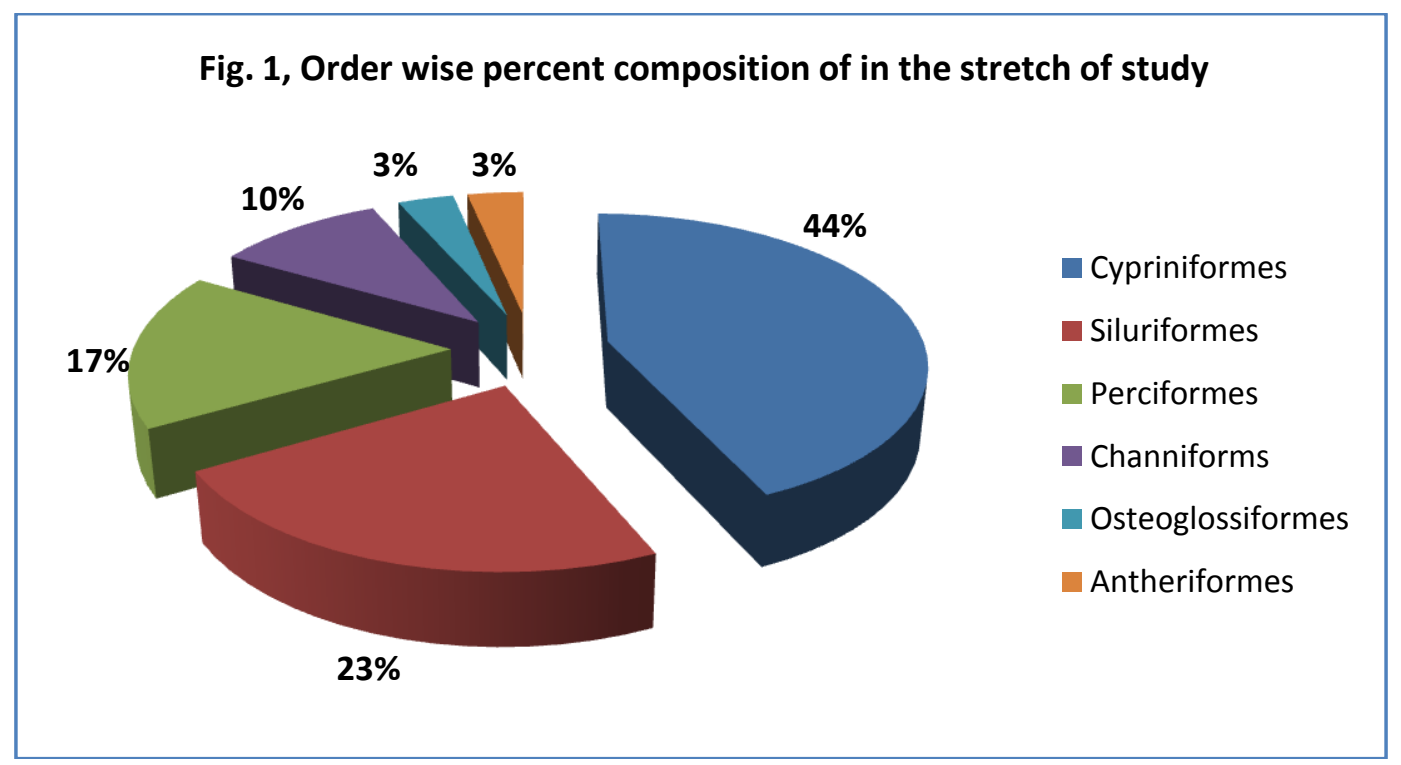


Table-2 showing The Diversity of Fishes in Nagaram tank during 2007 - 2010

\begin{tabular}{|c|c|c|c|}
\hline Order & Family & Species & Local Name \\
\hline \multirow{13}{*}{$\begin{array}{l}\text { Cypriniform } \\
\text { es }\end{array}$} & \multirow{12}{*}{ Cyprinidae } & Catla Catla (Hamilton - Buchanan) & Botcha \\
\hline & & Cirrihinus mrigala (Hamilton - Buchanan) & Merige \\
\hline & & Labeo rohita (Hamilton - Buchanan) & Rohu \\
\hline & & Labeo potail (Sykos) & Bocche \\
\hline & & Labeo pongusia (Hamilton - Buchanan) & Nalla Mossu \\
\hline & & Labeo calbasu (Hamilton - Buchanan) & Kaki boche \\
\hline & & Cyprinus carpio carpio (Hamilton - Buchanan) & Bangaru theega \\
\hline & & Punctius chola (Hamilton - Buchanan) & Parka \\
\hline & & Punctius ticto ticto (Hamilton - Buchanan) & Budda parka \\
\hline & & Punctius sarana sarana(Hamilton - Buchanan) & Gunda parka \\
\hline & & Amblyphaiyngodon mola (Hamilton) & Kodipe \\
\hline & & Salmostoma bacaila (Hamilton) & Chandamama \\
\hline & Cotibidae & Lepidocephalus guntea (Hamilton) & Ulsha \\
\hline \multirow{7}{*}{ Siluriformes } & Clariidae & Clarias batrachus (Linnaeus) & Marphoo \\
\hline & Heteropneustidae & Heteropneustes fossilis (Bloch) & Inglikam \\
\hline & \multirow{3}{*}{ Bagridae } & Mystus bleeker (Day) & Jella \\
\hline & & Mystus vittatus (Bloch) & Erra Jella \\
\hline & & Mystus cavasius (Hamilton) & Guddi Jella \\
\hline & Siluridae & Wallago attu (Schneider) & Valugu \\
\hline & & Ompak bimaculatus (Bloch) & Bugga damma \\
\hline \multirow{5}{*}{ Perciformes } & Atiabantidae & Anabus testudineus (Bloch) & Burka \\
\hline & \multirow[t]{2}{*}{ Mastacemblidae } & Mastacembelus armatus (Lacepede) & Paapera \\
\hline & & Mastacembelus puncalus (Hamilton) & Chinni Paapera \\
\hline & Gobiidae & Glosogobius giuris giuris (Hamilton) & $\begin{array}{l}\text { Uske danthi/ } \\
\text { Shala } \\
\text { Korramatta }\end{array}$ \\
\hline & Nandidae & Nandus nandus (Hamilton) & Pandiparka \\
\hline \multirow{3}{*}{ Channiforms } & \multirow{3}{*}{ Channidae } & Channa punctatus (Bloch) & Mottapilla \\
\hline & & Channa striatus (Bloch) & $\begin{array}{l}\text { Murrel or } \\
\text { Korramatta }\end{array}$ \\
\hline & & Channa orientalis (Hamilton) & Malapankidi \\
\hline $\begin{array}{l}\text { Osteoglossifo } \\
\text { rmes }\end{array}$ & Notopteridae & Notopterus notopterus (Pallas) & Vollenka \\
\hline $\begin{array}{l}\text { Antheriform } \\
\text { es }\end{array}$ & Belondae & Xenontodon cancila (Hamilton) & Nayanikunta \\
\hline
\end{tabular}

\section{References}

[1] Dua Anish and Chander Prakash (2009): Distribution and abundance of fish populations in Harrike wetland - A, Ramsar site in India. J. Environ. Biol. 30(2), 247-251.

[2] Battul, P.N., Rao K.R., Navale R.A., Bagale M.B. and Shah N.V. (2007): Fish diversity from Ekrukh lake near Solapur, Mahrashtra. J. Aqua. Biol., 22(2): 68-72.

[3] Chandrashekar, S.V.A., Nalini C. and Kodarkar M.S. (2004): "Limnological studies with reference to pisciculture, case study of Saroornagar Lake, Hyderabad (AP). J. Aqua. Biol, 19 (1): 197-200.

[4] Das, S.K. and Chand B.K. (2003): Limnology and biodiversity of ithchyofauna a pond of Southern Orissa. J. Ecotoxic. Environ. Monit. 13(2): 97-102.

[5] Day, F. (1875): The fishes of India, being a natural history of the fishes known to inhabit the seas and freshwaters of India, Burma and Ceylon., Test and atlas, 4 ports London.

[6] Day, F. (1878): The fishes of India being a natural history of fishes known to inhabit the seas and fresh waters of India, Barma and Ceylon. Text and Arlas in 4 parts, London.

[7] Dhankad, N.K., Deepak Shindey and Preethi Chandhery (2008): Fish fauna of Mod Sagar reservoir of Jhabue district. Nature, Environmental and Pollution Technology, Vol. 7, No.1. Pp.159-161.

[8] Dutta, S.K., Z. Changsan, and M.K. Choudhary. (2001): Application of biological monitoring in water quality assessment, biomonitoring and zooplankton diversity. (Ed. B.K. Sharma) Department of Zoology. NEHU, Shillong. Pp.164-173.

[9] Dutta, M.J.S. and M.P. Srivastava. (1988): Natural history of fish and systematic of freshwater fishes of India. Narendra Publishing House, New Delhi, pp. 10-15.

[10] Gadgil, M. (1996): Documenting diversity: an experiment Current Science. (70): 36-44. 
[11] Goswami, T.K and M.M. Goswami. (2006): Ichthyofaunal diversity and catch statistics of 'Jasmalis method in Kamrup district of Assam, India".

[12] Jayabhaye, U.M., Madlapure U.R. and Malviya M.K. (2006): Study of fish diversity in the Parola Dam near Hingoli, Hingoli district, Maharashtra, India. J. Aqua.Biol., 21(2): 65-66.

[13] Jayaram K.C. (1981): "The Fresh water fishes of India". ZSI. 1-438.

[14] Jayaram, K.C. (1999): The fresh water Fishes of the Indian Region. Narendra Publishing House, Delhi.: 551

[15] Jhingram, V.G. (1983): Fish and Fisheries of India, Hindustan Publisning Corporation(India), Delhi.

[16] Krishna.M and Piska. R.S. (2006): Ichthyofaunal diversity in Secret lake Durgam Cheruvu, Rangareddy district, Andhra Pradesh, India. J. Aqua. Biol. Vol. 21(1): 77-79.

[17] Kulkarni, M.Y., Kulkarni, A.N. and Somvamshi V.S (2008): A Study on some aspects of Reservoir Fisheries of Derala Tank, Dist. Nanded, Maharashtra. Proceedings of Taal 2007; The 12th World Lake Conference: 568-570.

[18] Menon, A.G.K. (1988): Checklist of freshwater fishes of India. Zoological Survey of India; (ZSI) Kolkata. pp. $65-66$.

[19] Menon, A.G.K. (1999): Checklist of freshwater fishes of India. Z. S. I. Kolkata.

[20] Mishra, K.S. (1962): An aid to the identification of the common commercial fishes of India and Pakistan. Rec. Indian Mus.

[21] Mishra, S., Pradham, P., Kar, S. and Chakraborthy, S.K. (2003): Ichthyofauna diversity of Midnapore, Bankura and Hooghly districts of South West Bengal. Rec. Zool. Surv. India. Occ. Paper 2220 : 1-66.

[22] Murthy, D.S. (2002): Highlights of fisheries development in Andhra Pradesh. Fishing Chimes. 22 (1): 64 - 70.

[23] Negi K.S (2009) : Ichthyofauna of Katarniaghat wildlife sanctuary, Uttar Pradesh, Uttar Pradesh J. Zool. 29(1) : 233-237.

[24] Nooralam, M.P., Saw, K and Mishra, S.K. (2009): Preliminary study of Physico-chemical characteristics of perennial fresh water pond. Flora and Fauna 15(1): 77-82.

[25] Pathak, S.K. and Mudgal L.K. (2005): Limnology and biodiversity of fish fauna in Viral reservoir, M.P.J. Comp Toxical physicochecmical. 2 (1 and II): 86-90.

[26] Pawar. B.A and Pandarkar A.K (2011) : Studies on water quality of Kelewadi lake in relation to Pisciculture, Maharashtra, Uttar Pradesh. J. Zool. 31(1): 35-41.

[27] Pawar. B.A. and Shendge, A.N. (2009) : Studies on water quality of Ashwi reservoir in relation to pisciculture, Ahmednagar district, Maharashtra, J. Exp. Zool. India 12(2) : 361-364.

[28] Pawar S.K. J.S. Pulle and K.M. Shendge (2006). The study on phytoplankton of Pethwadaj Dam, Taluka Kandhar, District - Nanded, Maharashtra. J. Aqua, Biol. 21. (1): 1-6.

[29] Ramu .G., B. Ravindar, K. Narasimha Ramulu and G. Benarjee (2009) : The Fish Fauna of Mylaram Reservoir in Warangal District, Andhra Pradesh. Aquacutt. Vol. 10(2), 313-316.

[30] Ravindar.B. (2010): "Studies on the ecology and fish fauna of fresh water bodies in Warangal District" Ph.D., Thesis, Kakatiya University, Warangal, Andhra Pradesh.

[31] Rohankar, L.H. (2009) : Study of some physico-chemical and biological parameter Rural lake Aheri, dist, Gadchiroli, Maharashtra, India. Ph.D. thesis, Nagpur University, Nagpur (Maharashtra).

[32] Sarkar, L. and Benerjec, S. (2000): Ichthyofauna of Damodar river system proc. Zool. Soc. Calcutta, 53(1): 41-54.

[33] Sharma, S.V. and Nayak D.Y. (2001): Checklist of fishes inhabiting in water bodies in Nallamala hill range in Andhra Pradesh. $J$. Aqua. Biol. 16(1): 35-36.

[34] Sharma, K.K., Nitasha and Sarbiet Kour (2007): Some limnological investigations in Banganga stream Koba. Jammu and Kashmir State. J. Aqua. Biol. Vol. 22(1) : 105-109.

[35] Sharma, Archana, Mudgal, L.K.Sharma, Anjana and Sharma Shailendra(2004): Fish diversity of Yashwant Sagar reservoir, Indore, (M.P.). Him. J.Env. Zool., 18(2):

[36] Srivastava, C.B.L. (1985): A text book of fisheries science and inland fisheries. Kitab Mahal, Allahabad.

[37] Talwar, P.K. and A.G. Jhingran. (1991): Inland fishes of India and adjacent countries. Oxford and IBH Publishing Co. Pvt. Ltd., New Delhi, pp. 1-322.

[38] Vijaykumar, K. and Paul R. (1990): Physico-chemical studies of Bhogsa reservoir in Gulbarga, Karnataka. Eco. Biol. 2 (4): 332 335 .

[39] Vyas. Vipin, Vivek Parashar and Dinesh Damde (2009): Fish Biodiversity and Preferential Habitats of Fishes in selected stretch of Narmada River. Nat. Environ. and. Pollu. Tech. Vol.8. No.1. 81-89.

[40] Yadav, B.E. (2006): Pisces, Fauna of Tadoba Andhari Tiger Reserve, Conservation Area Series. (25): 137-160. 